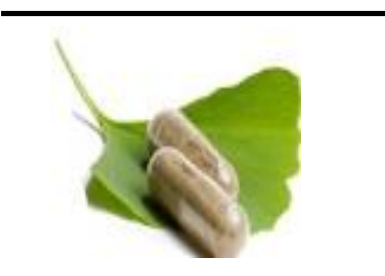

\title{
INTERNATIONAL JOURNAL OF PHARMACEUTICAL SCIENCES AND RESEARCH
}

Received 4 January, 2010; received in revised form 20 January, 2010; accepted 28 January, 2010

\section{PHOSPHATIDYLCHOLINE: A REVOLUTION IN DRUG DELIVERY TECHNOLOGY}

P. VERMA ${ }^{* 1}$, A. RAM ${ }^{2}$, A. K. JHA ${ }^{1}$, A. MISHRA $^{1}$, A. THAKUR $^{3}$

Shri Shankaracharya Institute of Pharmaceutical Science ${ }^{* 1}$, Bhilai (C.G.), India

SLT Institute of Pharmaceutical Sciences, Guru Ghasidas Vishwavidyalaya ${ }^{2}$, Bilaspur (C.G.), India

School of Pharmacy, Choukse Engineering College ${ }^{3}$, Bilaspur (C.G.), India

Keywords:

Phosphatidylcholine,

Vesicular systems,

Membrane

*Correspondence for Author

P. Verma

Shri Shankaracharya Institute of Pharmaceutical Science, Bhilai (CG) India

E-mail:

parma_pharma@rediffmail.com

\begin{abstract}
In recent years Phosphatidylcholine has greatly impacted the drug delivery technology. The very first and most important advantage of phospholipid based vesicular system is the compatibility of phospholipids with membrane of human either internal membrane as well as skin (external membrane). For a drug to be absorbed and distributed into organs and tissues and eliminated from the body, it must pass through one or more biological membranes/ barriers at various locations. Such a movement of drug across the membrane is called as drug transport. For the drugs to be delivered to the body should cross the membranous barrier. Either it would be from oral route or topical/transdermal route. Therefore the phospholipid based carrier systems are of considerable interest in this era. A number of drug delivery systems are based entirely on Phosphatidylcholine such as Liposome, Ethosome, Phytosome, Transferosomes, and Nanocochelates.
\end{abstract}




\section{INTRODUCTION:}

Since last decades the popularity of vesicular systems has been increased because of a lot of advantages associated with it. Vesicular systems are mainly composed of phospholipids. Phospholipids are amphipathic (having affinity for both aqueous and polar moieties) molecules as they have a hydrophobic tail and a hydrophilic or polar head.

The hydrophobic tail is composed of two fatty acid chains containing 10-24 carbon atoms and 0-6 double bonds in each chain. The polar end of the molecule is mainly phosphoric acid bound to a water- soluble molecule. The hydrophilic and hydrophobic domains/ segments within the molecular geometry of amphiphilic lipids orient and self organize in ordered supramolecular structure when confronted with solvents ${ }^{1}$. Some commonly used synthetic phospholipids are dioleoyl- phosphatidyl- choline (DOPC), Dioleoyl-phosphatidylethanolamine (DOPE), Distearoylphosphatidyl- choline (DSPC), Distearoylphosphatidyl- ethanolamine (DSPE) ${ }^{2}$.

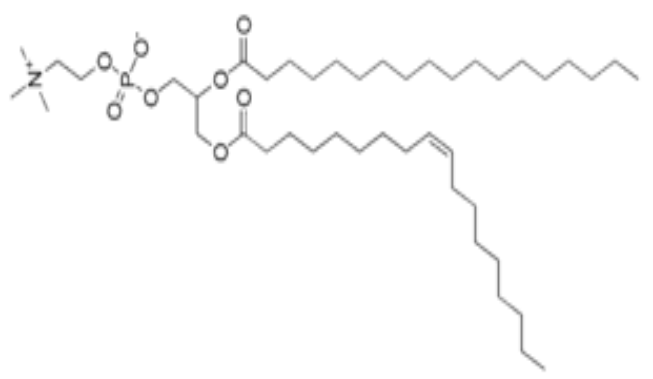

Fig 1: Phophatidylcholine containing oleyl and stearoyl side chains. ${ }^{3}$
Among these all phospholipids, phosphatidylcholine classes of phospholipids are very important in the drug delivery technology.

The very first and most important advantage of phospholipid based vesicular systems is the compatibility of phospholipids with membrane of human either internal membrane as well as skin. For a drug to be absorbed and distributed into organs and tissues and eliminated from the body, it must pass through one or more biological membranes/ barriers at various locations. Such a movement of drug across the membrane is called as drug transport. The cellular membrane consists of a double layer of amphiphilic phospholipids molecules arranged in such a fashion that their hydrocarbon chains are oriented inwards to form the hydrophobic or lipophilic phase and their polar heads oriented to form the outer and inner hydrophilic boundaries of the cellular membrane that face the surrounding aqueous environment.

Globular protein molecules are associated on either side of these hydrophilic boundaries and also interspersed within the membrane structure. In short, the membrane is a mayonnaise sandwich where a bimolecular layer of lipids is contained between two parallel monomolecular layers of proteins. The hydrophobic core of the membrane is responsible for the relative impermeability of polar molecules. Aqueous filled pores or perforations of 4 to $10 A^{0}$ in diameter are also present in the membrane structure through which organic ions and small organic water- soluble molecules like urea can pass. In general, the biomembrane 
acts like a semi permeable barrier permitting rapid and limited passage of some compounds while restricting that of others ${ }^{4}$. The $\mathrm{Gl}$ linings constituting the absorption barrier allows most nutrients like glucose, amino acids, fatty acids, vitamins, etc., to pass rapidly through it into the systemic circulation but prevent the entry of certain toxins and medicaments. Thus, for a drug to get absorbed after oral administration, it must first pass through this biological barrier ${ }^{4}$.

And for topical/ transdermal delivery of drugs, it has to cross the skin. During the past decades there has been wide interest in exploring new techniques to increase drug absorption through skin ${ }^{5}$, 6,7 . Topical delivery of drugs by lipid vesicles has evoked a considerable interest. The skin, the heaviest single organ of the body, combines with the mucosal linings of the respiratory, digestive, and urogenital tracts to form a capsule, which separates the internal body structures from the external environment. The skin has various functions such as protection from external environment, maintenance of body posture, regulation of temperature, etc. Including these various primary functions, it also acts as a site for drug delivery.

The skin itself has two main layers: the epidermis, which is the outermost layer of the skin, covering the dermis that is the active part of the skin, holding the hair muscles, blood supply, sebaceous glands, and nerve receptors. There is a fat layer underneath the dermis. The skin is a very heterogeneous membrane and has a variety of cell types, but the layer that controls the penetration of drugs is called the stratum corneum and, despite its thickness of only 15-20 $\mu \mathrm{m}$, it provides a very effective barrier to penetration. The permeation of the drug through the skin has several routes: transcellular, intercellular, and appendageal (through eccrine (sweat) glands or hair follicles). Since the appendages occupy a very low surface area, this means of permeation is less significant under normal conditions ${ }^{8}$.

Nevertheless, in iontophoretics delivery this route is more significant ${ }^{9}$. So for the drugs to be delivered to the body should cross the membranous barrier. Either it would be from oral route or topical/transdermal route. Therefore the phospholipid based carrier systems are of considerable interest in this era.

History: Phosphatidylcholine was first isolated in Odessa, Ukraine some 50 years ago. This was followed by further research in Germany and Russia. It has been marketed by Sanofi- Aventis for over 30 years and, at present; the substance phosphatidylcholine is registered in 53 countries. Its main application nowadays lies in the intravenous treatment and prevention of fat embolisms in polytraumatized patients in the treatment of metabolic disorders and as a liverprotecting substance ${ }^{10}$.

Mechanism of vesicle formation: In aqueous medium the molecules in selfassembled structures are oriented in such a way that the polar portion of the molecule remains in contact with the polar environment and at the same time shields the non-polar part. Among the amphiphilic used in the drug delivery, viz soaps, detergents, polar lipids, the latter (polar lipids) are often employed to form 
concentric bilayered structures. However, in aqueous mixtures these molecules are able to form various phases, some of them are stable and others remain in the metastable state ${ }^{11}$. At high concentrations of these polar lipids, liquid- crystalline phases are formed that upon dilution with an excess of water can be dispersed into relatively stable colloidal particles. The macroscopic structures most often formed include lamellar, hexagonal or cubic phases dispersed as colloidal nanoconstructs (artificial membranes) referred to as liposomes, hexasomes or cubosomes, respectively ${ }^{12}$. The most common natural polar phospholipids are Phophatidylcholine (PC).

These are amphipathic molecules in which a glycerol bridges links to a pair of hydrophilic polar head group, phosphatidylcholine. Fatty chains are embedded in the hydrophilic inner region of the membrane surface, the hydrophilic head group, including the phosphate portion, points out towards the hydrophilic aqueous environment. Molecules of PC are not soluble ( rather dispersible) in aqueous milieu in the physical chemistry sense, as in aqueous media they align themselves closely in planer bilayer sheets to minimize the unfavorable interactions between the bulk aqueous phase and long hydrocarbon fatty acyl chain. Such interactions are completely eliminated when the sheets fold over themselves to form closed sealed and concentric vesicles.

The large free energy change between an aqueous and hydrophobic environment explains the most favored orientation of lipids to assemble as concentric bilayer structures that exclude confrontation between aqueous and hydrophobic domains. This distinctive behavior derives in the lowest free energy state and hence ensures the maximum stability to self- assembled structures ${ }^{11}$. The phosphatidylcholine and its synthetic analogues differ markedly from amphiphilic molecules of differ markedly from amphiphilic molecules of other origin ( soaps, detergents, lysolecithin ) in that they preferably orient to form bilayer sheets rather than micellar structures.

This presumably attributed to the double fatty acid chain that imparts the molecule an overall tubular shape are more suitable for assemblage in planer sheets. In contrast, the detergent molecule with a polar head and single acyl chain has a conical shape and facilitate the formation of spherical micellar structures. Depending on the hydrophobic environment and aqueous phase, homogenous smectic phases of parallel lipid bilayers (lyotropic phases) or heterogeneous dispersion of multilamellar or single- walled vesicles can be observed.

At lower water content and higher temperature, other lyotropic liquid crystalline phases exist, such as the hexagonal, the cubic and the ribbon phases. Table presents different vesicle forming lipids with their molecular weights and phase transition temperature $\left(T c^{0}\right)$. The vesicles have been well known for their importance in cellular communication and particle transportation for many years. Researchers have understood the properties of vesicles structure for use in better drug delivery within their cavities, 
which would to tag the vesicle for cell specificity.

Advantages of phospholipid based carrier systems ${ }^{2}$ in comparison to other delivery systems:-

1. These systems show enhanced permeation of drug through skin for transdermal and dermal delivery.

2. These are platform for the delivery of large and diverse group of drugs (peptides, protein molecules).

3. Their composition is safe and the components are approved for pharmaceutical and cosmetic use.

4. Low risk profile- The toxicological profiles of the phospholipids are well documented in the scientific literature.

5. High market attractiveness for products with proprietary technology. Relatively simple to manufacture with no complicated technical investments required for production of Ethosomes.

6. The vesicular system is passive, noninvasive and is available for immediate commercialization.

Brief introduction to the phospholipid based carrier systems:

Liposome: Liposomes are colloidal, vesicular structures composed of one or more lipid bilayers surrounding an equal numbers of aqueous compartments. Since, 1960's pharmaceutical researchers used liposomes as therapeutic tools in medicinal field. A number of liposomal formulations of such drugs have available in the market such as Doxil (Doxorubicin), Fungizone ${ }^{\circledR}$ (Amphotericin-
B), Novasome (Smallpox vaccine) and Nyotran $^{\text {TM }}$ (Nystatin). Liposomes used as potential carriers in field like tumor targeting, gene and antisense therapy, genetic vaccination, immunomodulation and skin care and topical cosmetics products. The present review highlights the composition, method of preparation, characterization, therapeutic applications of liposomes and its marketed products ${ }^{13}$.

Ethosome: Ethosomes are soft, malleable vesicles composed mainly of phospholipids, ethanol (relatively high concentration) and water. These "soft vesicles" represents novel vesicular carrier for enhanced delivery to/through skin. The size of Ethosomes vesicles can be modulated from tens of nanometers to microns.

Ethosomes are provides a number of important benefits including improving the drug's efficacy, enhancing patient compliance and comfort and reducing the total cost of treatment. The Ethosomes were found to be suitable for various applications within the pharmaceutical,biotechnology, veterinary, cosmetic, and nutraceutical markets ${ }^{14}$.

Phytosome: Phytosome are created when the standardized extract and active ingredients of an herb are bound to the phospholipids on a molecular level. Phytosome structures contain the active ingredients of the herb surrounded by the phospholipids. The phospholipid molecular structure includes a watersoluble head and two fat-soluble tails, because of this dual solubility, the phospholipid acts as an effective emulsifier, which is also one of the chief components of the membranes in our cells. Phytosomes are advanced forms of 
herbal products that are better absorbed, utilized, and as a result produce better results than conventional herbal extracts ${ }^{15}$.

Transferosomes: In functional terms, may be described as lipid droplets of such deformability that permits its easy penetration through the pores much smaller than the droplets size. Transferosomes have been developed in order to take advantage of phospholipids vesicles as transdermal drug carrier.

These self optimized aggregates, with ultraflexible membrane, are able to deliver the drug reproducibly either into or through the skin, depending on the choice of administration or application, with high efficiency. Transferosomes overcome the skin penetration difficulty by squeezing themselves along the intracellular sealing lipids of stratum corneum. There is provision for this, because of the high vesicle deformability, which permits the entry due to mechanical stress of surrounding, in a self adapting manner.

Flexibility of transferosomes membrane is achieved by mixing suitable surface active agents in the proper ratios. The resulting flexibility of transferosome membrane minimize the risk of complete vesicle rupture in the skin and allow transferosomes to follow the natural water gradient across the epidermis , when applied under non occlusive condition. Transferosomes can penetrate the intact stratum corneum spontaneously either through intracellular route or transcellular route ${ }^{16}$.
Long circulating liposomes: The major limitation of liposomes is their fast elimination from the blood and localization in reticuloendothelial system primarily kupfer cells of liver. Different methods have been reported to achieve long circulation of liposomes in vivo, including modification with certain lipids such as monosialoganglioside, palmityl-DGlucoronic acid and PEG-PE. These liposomes show significantly longer circulation in blood than the liposomes without these lipids ${ }^{17,18,19,20,21}$.

Nanocochelates: Nanocochelates consists of a purified soy based phospholipid that contains at least about $75 \%$ by weight of lipid which can be phosphatidyl- serine (PS), dioleoyl-phosphatidyl-serine (DOPS), phosphatidic acid (PA), phosphatidylinositol (PI), phosphatidyl glycerol (PG) and /or a mixture of one or more of these lipids with other lipids. Additionally or alternatively, the lipid can include phosphatidylcholine (PC), phosphatidylethanolamine (PE), diphosphotidylglycerol (DPG), dioleoyl phosphatidic acid (DOPA), distearoyl phosphatidylserine (DSPS), and dimyristoyl phosphatidylserine (DMPS), dipalmitoyl phosphatidylgycerol (DPPG) ${ }^{7}$.

A multivalent cation, which can be $\mathrm{Zn}^{+2}$ or $\mathrm{Ca}^{+2}$ or $\mathrm{Mg}^{+2}$ or $\mathrm{Ba}^{+2}$ and a drug, which can be protein, peptide, polynucleotide, antiviral agent, anesthetic, anticancer agent, immunosuppressant, steroidal anti inflammatory agent, non steroidal anti inflammatory agents, tranquilizer, nutritional supplement, herbal product, vitamin and/or vasodilatory agent ${ }^{22}$. 
Application of phospholipid based carrier systems:

\section{Liposomes}

Table 1: Therapeutic applications of liposomes:

\begin{tabular}{|c|c|c|c|}
\hline Drug & Route of administration & Application & Targeted Diseases \\
\hline Amphotericin- $\mathrm{B}^{23}$ & Oral delivery & Ergosterol membrane & Mycotic infection \\
\hline Insulin ${ }^{24}$ & $\begin{array}{l}\text { Oral, Ocular, Pulmonary and } \\
\text { Transdermal delivery }\end{array}$ & Decrease glucose level & Diabetic mellitus \\
\hline Ketoprofen ${ }^{26}$ & Ocular delivery & $\begin{array}{c}\text { Cyclo-oxygenase enzyme } \\
\text { inhibitor }\end{array}$ & Pain muscle condition \\
\hline Pentoxyfylline ${ }^{26}$ & Pulmonary delivery & Phosphodiesterase & Asthma \\
\hline Tobramycin $^{27}$ & Pulmonary delivery & Protein synthesis inhibitor & $\begin{array}{c}\text { Pseudomonas infection, } \\
\text { aeruginosa }\end{array}$ \\
\hline Salbutamol $^{28}$ & Pulmonary delivery & $\beta_{2}$ - adrenoceptor antagonist & Asthma \\
\hline Cytarabin $^{29}$ & Pulmonary delivery & DNA-polymerase inhibition & Acute-leukemias \\
\hline Benzocain $^{30}$ & Transdermal & $\begin{array}{l}\text { Inhibition of nerve impulse } \\
\text { from sensory nerves }\end{array}$ & $\begin{array}{c}\text { ulcer on mucous surface } \\
\text { with pain }\end{array}$ \\
\hline Ketoconazole $\mathrm{e}^{30}$ & Transdermal & Inhibit ergosterol membrane & Candida- albican's \\
\hline Levonogesterol $^{30}$ & Transdermal & Rhamnose receptor & Skin disorder \\
\hline Hydroxyzine ${ }^{30}$ & Transdermal & $\mathrm{H}_{1}$ - receptor antagonist & $\begin{array}{l}\text { Urtecaria, allergic skin } \\
\text { disorder }\end{array}$ \\
\hline Ibuprofen ${ }^{30}$ & Oral delivery & $\begin{array}{c}\text { Chemoreceptor, free nerve } \\
\text { ending }\end{array}$ & Rheumatoid arthritis \\
\hline $\begin{array}{l}\text { Pentamidine } \\
\text { isethionate }^{30}\end{array}$ & Oral delivery & Killed protozoa & Protozoal infection \\
\hline Idoxiuridine ${ }^{30}$ & Ocular delivery & $\begin{array}{l}\text { DNA-synthesis, Protein } \\
\text { synthesis }\end{array}$ & $\begin{array}{l}\text { Herpex- simplex, } \\
\text { Keratitis }\end{array}$ \\
\hline Adrenaline $e^{30}$ & Ocular delivery & $\begin{array}{l}\text { Decreases intra-ocular } \\
\text { pressure }\end{array}$ & Glucoma, Conjectivitis \\
\hline Triamcinolone $e^{30}$ & Ocular delivery Transdermal & Inhibition of prostaglandin & Anti-inflammatory \\
\hline Penicillin $\mathrm{G}^{30}$ & Pulmonary delivery & $\begin{array}{l}\text { Inhibit synthesis of bacterial } \\
\text { cell wall }\end{array}$ & $\begin{array}{c}\text { Meningococal, } \\
\text { staphylococcal infection }\end{array}$ \\
\hline $\begin{array}{l}\text { Terbutaline } \\
\text { sulphate }^{30}\end{array}$ & Pulmonary delivery & $\beta_{2}$ - adrenoceptor & Asthma \\
\hline Methotrexate ${ }^{30}$ & Transdermal & Dihydrofolate reductase & Cancer \\
\hline Doxorubicin $^{31,32}$ & Oral delivery & Inhibit DNA/ Protein synthesis & Cancer \\
\hline
\end{tabular}


Table 2: list of marketed products of Liposome

\begin{tabular}{|c|c|c|c|}
\hline $\begin{array}{l}\text { Marketed } \\
\text { product }\end{array}$ & Drug used & Target diseases & Company \\
\hline Doxil $^{\text {TM }}$ or Caelyx ${ }^{\text {TM33 }}$ & Doxorubicin & Kaposi's sarcoma & SEQUUS, USA \\
\hline DaunoXome $e^{\mathrm{TM} 34}$ & Daunorubicin & $\begin{array}{c}\text { Kaposi's sarcoma, breast \& lung } \\
\text { cancer }\end{array}$ & NeXstar, USA \\
\hline Amphotec $^{\mathrm{TM} 35}$ & Amphotericin-B & fungal infections, Leishmaniasis & SEQUUS, USA \\
\hline Fungizone ${ }^{\circledR} 36$ & Amphotericin-B & fungal infections, Leishmaniasis & Bristol-squibb, Netherland \\
\hline VENTUS $^{\text {TM } 12}$ & Prostaglandin- $\mathrm{E}_{1}$ & Systemic inflammatory diseases & The liposome company, USA \\
\hline $\mathrm{ALEC}^{\mathrm{TM} 37}$ & $\begin{array}{l}\text { Dry protein free } \\
\text { powder of DPPC- } \\
\text { PG }\end{array}$ & Expanding lung diseases in babies & Britannia Pharm, UK \\
\hline Topex- $\mathrm{Br}^{34}$ & $\begin{array}{l}\text { Terbutaline } \\
\text { sulphate }\end{array}$ & Asthma & Ozone, USA \\
\hline Depocyt $^{38}$ & Cytarabine & Cancer therapy & Skye Pharm, USA \\
\hline Novasome ${ }^{38}$ & Smallpox vaccine & Smallpox & Novavax, USA \\
\hline $\begin{array}{l}\text { Avian retrovirus } \\
\text { vaccine }^{39}\end{array}$ & $\begin{array}{l}\text { Killed avian } \\
\text { retrovirus }\end{array}$ & Chicken pox & Vineland lab, USA \\
\hline $\begin{array}{l}\text { Epaxal -Berna } \\
\text { Vaccine }^{39}\end{array}$ & $\begin{array}{l}\text { Inactivated } \\
\text { hepatitis-A Virions }\end{array}$ & Hepatitis A & $\begin{array}{l}\text { Swiss serum \& vaccine institute, } \\
\text { Switzerland }\end{array}$ \\
\hline Doxil 40 & Doxorubicin $\mathrm{HCl}$ & Refractory ovarian cancer & ALZA, USA \\
\hline Evacet $^{\mathrm{TM} 41}$ & Doxorubicin & Metastatic breast cancer & The liposome company, USA \\
\hline VincaXome $e^{41}$ & Vincristine & Solid Tumours & NeXstar, USA \\
\hline Mikasome $^{41}$ & Amikacin & Bacterial infection & NeXstar, USA \\
\hline Autragen $^{\text {TM } 41}$ & Tretinoin & Kaposi's sarcoma & Aronex Pharm, USA \\
\hline $\begin{array}{l}\text { Shigella Flexneri } 2 \mathrm{~A} \\
{ }^{41} \text { Vaccine }\end{array}$ & Shigella flexneri $2 \mathrm{~A}$ & Shigella Flexneri $2 \mathrm{~A}$ infections & Novavax, USA \\
\hline Nyotran $^{\text {TM } 41}$ & Nystatin & Systemic fungal infections & Aronex Pharm, USA \\
\hline
\end{tabular}

\section{Ethosome:-}

Table 3: Therapeutic applications of Ethosomes

\begin{tabular}{|c|c|c|}
\hline Drug & Applications & Comments \\
\hline Acyclovir $^{42}$ & Treatment of Herpetic infection & Improved drug delivery \\
\hline Zidovudine ${ }^{43}$ & Treatment of AIDS & Improved transdermal flux \\
\hline $\begin{array}{l}\text { Trihexypenidyl } \\
\qquad \mathrm{HCl}^{44,45}\end{array}$ & $\begin{array}{l}\text { Treatment of Parkinsonian } \\
\text { syndrome }\end{array}$ & $\begin{array}{l}\text { Increased drug entrapment efficiency, } \\
\text { reduced side effect \& constant systemic levels }\end{array}$ \\
\hline Erythromycin ${ }^{46}$ & $\begin{array}{l}\text { Efficient healing of S. aureus - } \\
\text { induced deep dermal infections }\end{array}$ & $\begin{array}{c}\text { Improved drug penetration and systemic } \\
\text { effect. }\end{array}$ \\
\hline Insulin 47 & Treatment of Diabetes & Improved therapeutic efficacy of drug \\
\hline Testosterone $^{48}$ & Treatment of male hypogonodism & Enhance skin permeation \\
\hline Cannabidol $^{49}$ & Prevents inflammation and edema & $\begin{array}{l}\text { Significant accumulation of the drug in the } \\
\text { skin }\end{array}$ \\
\hline Minodixil $^{50}$ & Hair growth promotion effect & Higher skin retention \\
\hline Bacitracin $^{51}$ & Treatment of dermal infections & Reduced drug toxicity \\
\hline
\end{tabular}




\section{Phytosome:-}

Table 4: Therapeutic applications of Phytosomes

\begin{tabular}{ccc}
\hline Molecule & Application & Targeted Diseases \\
\hline Botanical extracts $^{52}$ & $\begin{array}{l}\text { Enhance bioavailability due to their } \\
\text { complex with phospholipids and delivers } \\
\text { faster and improved absorption in } \\
\text { intestinal tract. }\end{array}$ & Diabetic mellitus \\
$\begin{array}{c}\text { Non-lipophilic botanical } \\
\text { extract }\end{array}$ & To be better absorbed in intestinal \\
$\begin{array}{c}\text { Cosmetics, gap junction } \\
\text { protein }^{53}\end{array}$ & Transdermal immunization & For treatment of Infections \\
\hline
\end{tabular}

\section{Transferosomes:-}

Table 5: Therapeutic applications of Transferosomes

\begin{tabular}{|c|c|c|}
\hline Drug & Application & Targeted Diseases \\
\hline Insulin ${ }^{54}$ & $\begin{array}{l}\text { Decreases } \\
\text { glucose level }\end{array}$ & Diabetic mellitus \\
\hline $\begin{array}{l}\text { Interferons, for example leukocytic derived } \\
\text { interferone- } \alpha(\text { INF- } \alpha)^{54}\end{array}$ & $\begin{array}{l}\text { Antiviral, antiproliferive and some } \\
\text { immunomodulatory effects }\end{array}$ & $\begin{array}{l}\text { For treatment of } \\
\text { Infections }\end{array}$ \\
\hline $\begin{array}{c}\text { Soluble protein like integral membrane } \\
\text { protein, human serum albumin, gap junction } \\
\text { protein }^{54}\end{array}$ & Transdermal immunization & Immunization \\
\hline Corticosteroids ${ }^{54}$ & Treatment of skin diseases & Skin diseases \\
\hline Anesthetics ${ }^{54}$ & Topical anesthesia & $\begin{array}{l}\text { For the operation } \\
\text { purposes }\end{array}$ \\
\hline
\end{tabular}

5. Long circulating liposomes:-

Table 6: Therapeutic applications of long circulating liposomes

\begin{tabular}{ccc}
\hline Drug/ molecule & Application & Ligand \\
\hline Serum proteins $^{17}$ & Increase the circulating time & Sialic acid and glyco- conjugates \\
& & \\
\hline
\end{tabular}

\section{Nanocochelates}

Table 7: Therapeutic applications of Nanocochelates

\begin{tabular}{ccc}
\hline System & Application & Purpose \\
\hline $\begin{array}{c}\text { Biogeode }^{\text {TM }} \\
\text { Nanocochleates }^{55}\end{array}$ & $\begin{array}{c}\text { Stabilize and protect an extended range of micronutrients and the } \\
\text { potential to increase the nutritional value of processed foods } \\
\text { To deliver proteins, peptides and DNA }\end{array}$ & Nutrition \\
& $\begin{array}{l}\text { for vaccine and gene } \\
\text { therapy applications }\end{array}$ \\
Nanocochleates $^{55}$ & In the delivery of antibacterial agents: (clofazimine) & $\begin{array}{c}\text { For reducing the toxicity } \\
\text { and improving the } \\
\text { bactericidal activity }\end{array}$ \\
\hline
\end{tabular}




\section{CONCLUSION:}

A number of drug delivery systems are emerging today. But the delivery systems based on Phosphatidylcholine are of much importance because of intense advantages associated with them. The delivery systems described above have proved their ability and efficacy to deliver the active moiety to the desired location of the body. But this is not the limit of these Phosphatidylcholine based drug delivery systems. In future the Phosphatidylcholine based drug delivery systems can be utilized to the maximum to proof these systems as a revolution in drug delivery technology. This review is only an attempt to attract the attention of researchers to these types of systems.

\section{REFERENCES:}

1. Lasic DD: Liposome - A Practical Approach. Oxford University Press, Oxford. 1995: 112114.

2. Vyas SP and Khar RK: Liposome, Targeted \& Controlled Drug Delivery, CBS Publisher \& Distributors New Delhi. 2002; 174.

3. http://www.kvue.com/news/top/stories/1105 07kvuelipodissolve-mm.1e0189bdb.html

4. Brahmankar DM and Jaiswal SB: Biopharmaceutics and Pharmacokinetics - A Treatise, Ed. First, Reprint,Vallabh Prakashan, Delhi, 2006; 6-7.

5. Barry BW: Novel mechanisms and devices to enable successful transdermal drug delivery. European journal of pharmaceutical sciences 2001; 14: 101-114.

6. Williams A: Transdermal and topical drug discovery, $1^{\text {st }}$ ed. Pharmaceutical Press, London 2003; 122- 13.

7. Honeywell-Nguyen P.L. and Bouwstra J.A. Vehicles as a tool for transdermal and dermal delivery. Drug Discov. Today: technol., 2005; 2: 67-74.

8. Hadgraft J. International journal of pharmaceutics, 2001; 184(1): 1-6.

9. Jadoul A, Doucet J, Durand, D and Preat V. Journal of Control Release 1996; 42: 165.

10. Hasengschwandtner F. Phosphatidyl- choline treatment to induce lipolysis, Journal of Cosmetic Dermatology 4: 308-313.

11. Lasic DD. In: Liposomes; From biophysics to applications, Elsevier, New York, 1993: 9.

12. Lasic DD. Trends in Biotechnol 1998; 16: 307.

13. Patel S S: Liposome- A versatile platform for targeted delivery of drugs. Pharmainfo.net 2006 ; 4 (5):1-10

14. Patel SS: Ethosomes A Promising Tool For Transdermal Delivery Of Drug. Pharmainfo.net $2007 ; 5(2): 1-10$.

15. Darshan D: Phytosome- A Novel Dosage Structure. Pharmainfo.net 2007; 5(1):1-10.

16. Jain S, Sapee R and Jain N K: Proultraflexible lipid vesicles for effective transdermal delivery of norgesterol. proceedings of $25^{\text {th }}$ conference of C.R.S., U.S.A. 1998: 32-35.

17. Allen TM and Chonn A: Large unilamellar liposomes with low uptake into the reticuloendothelial system. FEBS Lett. 1987;223: 42-46.

18. Klibanov AL, Maruyama K, Torchilin VP and Huang L: Amphipathic polyethyleneglycols effectively prolong the circulation time of liposomes. FEBS Lett. 268: 1990; 235-237.

19. Blume $G$ and Cevc $G$ : Liposomes for the sustained drug release in vivo. Biochim. Biophys. Acta 1990;1029: 91-97.

20. Papahadjopoulos D, Allen TM, Gabizon A, Mayhew E, Matthay K, Huang SK, Lee KD, Woodle MC, Lasic DD, Redemann C and Martin FJ: Sterically stabilized liposomes: improvements in pharmacokinetics and antitumor therapeutic efficacy. Proc.Natl. Acad. Sci. U.S.A. 1991;88 11460-11464. 
21. Namba $Y$, Sakakibara $T$, Masada $M$, Ito $F$ and Oku N: 1-O-Palmityl- glucuronate endows liposomes with long half-life in vivo. Chem. Lett. 1989; 2145-2148.

22. Tan F, Zarif L: Cochleates made with purified soy phosphatidylserine. European patent 2005; 1494:690.

23. Zuidam N. J.and Crommelin D J A :, Journal of Pharmarmaceutical Science 1995 ; 84 :11131115.

24. Lohner K and Prenner E : Journal of Biochem. Biophys. Acta. 1999;1462:141-156.

25. Czech M P: Annu. Rev. Physiol., 1985;47:357383.

26. Vane J R, Botting R. and Faseb. J: 1987;1:8996.

27. Maries S J: Antimicrob Chemother 1994; 33:907-916.

28. Banerjee B, Nandi G, Mahato S B, Pakrashi A. and Basu $M$ K: Journal Antimocrob Chemother 1996;38:145-150.

29. Wolfe M S: Cli. North. America 1982; 66:707720 .

30. Vyas S P and Dixit V: In Advances in liposomal therapeutica, First Edition, CBS Publishers, New Delhi, 2001; 1:230-243.

31. Vaage J, Doonavan D, Loftus T, Abra R., Working P. and Hunag A: Cancer. 1994;73:2366-2368.

32. Muggia F M, Hainsworth J D, Jeffers ., Miller $P$, Groshen S, Tan M, Roman L, Uziely B, Burnett A and Greco F A: J. Clin. Oncol 1997;15:987989.

33. Working $P$ K, Newman $M S$ and Hunag $S$ K: Journal Liposomes Research 1994;4:667-669.

34. Chung K F and Barens P J: Drug of today 1989; 25:721-732.

35. Pretzer E, Flasher D and Duzgunes N: Antiviral Research 1997; 34:1-15.
36. Wasan M W and Lopez-Berestein G: In Medical applications of liposomes. Elsevier, Oxford 1998; 165-169.

37. Bangham A D, Standish M M and Watkins J C: Journal of Mol. Biology 1965;13:238-252.

38. Patil S G, Gattani S G, Gaud R S, Surana S J, Dewani S P and Mahajan H S: The Pharma Review 2005; 18(3):53-58.

39. Gregoriadis G, McCormack B, Perrie $Y$ and Saffie R: In Medical applications of liposomes. Elsevier, Oxford 1998; 61-65.

40. Forssen $E A$ and Ross $M$ E: Journal of Liposomes Research 1994; 4:481.

41. Vyas S P and Khar $\mathrm{R}$ K: Targeted and controlled drug delivery. First Edition, CBS Publishers, Delhi, 2002;219-243.

42. Horwitz E, Pisanty S, Czerninski R, Helser M, Eliav $E$, and Touitou $E$ : A clinical evaluation of a novel liposomal carrier for acyclovir in the topical treatment of recurrent herpes labialis, Oral Surg. Oral Med. Oral Pathol. Oral Radiol. Endod 1999;88:700-705.

43. Jain S, Umamaheshwari R B, Bhadra D, and Jain NK, Ethosomes-A novel vesicular carrier for enhanced transdermal delivery of an antiHIV agent, Indian Journal of Pharm. Science 2004;66(1):72-81.

44. Dayan N and Touitou E: Carrier for skin delivery of trihexyphenidyl $\mathrm{HCl}$ Ethosomes vs liposomes. Biomaterials 2002; 21:1879-1885.

45. Touitou E: Compositions for applying active substances to or through skin. US Patent 1996; 5540:934.

46. Godin B, Touitou E, Rubinstein E, Athamna A, and Athamna $\mathrm{M}$ : A new approach for treatment of deep skin infections by an ethosomal antibiotic preparation- an in vivo study, Journal of Antimicrobial Chemotherapy $2005 ;$ 55(6):989-994.

47. Touitou E, Godin B, Dayan N, Piliponsky A, Levi-Schaffer $F$, and Weiss $C$ : Intracellular delivery mediated by an ethosomal carrier, Biomaterials 2001;22:3053-3059. 
48. Kaplun Frisckhoff $\mathrm{Y}$ and Touitou E: Testosterone skin permeation enhancement by menthol through formation of eutectic with drug and interaction with skin lipids. Journal of Pharma Science 1997; 86:13941399.

49. Lodzki M, Godin B, Rakou L, Mechoulam R, Gallily R, and Touitou E: Cannabidol transdermal delivery and anti-inflammatory effect in a marine model. Journal Control Release 2003; 93:379-389.

50. Kim JC, Lee $\mathrm{MH}$, and Rang MJ: Minodixil containing dosage forms- skin retention and after rising hair growth promotion. Drug Delivery 2003; 10(2):119-123.

51. Goldin B and Touitou E: Mechanism of bacitracin permeation enhancement through the skin and cellular membrane from an ethosomal carrier. Journal Control. Release 2004; 94:365-379.
52. Allen $T$ M, Hansen $C$, Martin $F$, Redemann $C$ and Yau-Young A: Liposomes containing synthetic lipid derivatives of poly (ethylene glycol) show prolonged circulation half-lives in vivo. Biochim Biophys Acta $1991 ; 1066(1)$ : 2936.

53. Cevc G: Crit. Rev. There Drug Carrier System 1996; 13: 257-388.

54. Nanda A, Nanda S, Dhall $M$ and Rao R: transferosomes- A Novel Ultradeformable Vesicular Carrier for Transdermal Drug Delivery 2005 5( 9) : 395.

55. Jayraj: Nanocochelates- A Novel Drug Delivery Technology, Pharmainfo.net. 20086 (5) 2008: 54-58. 